\title{
OPPORTUNITIES AND CHALLENGES OF ORGANIZING AND IMPLEMENTING DISTANCE PRE-SCHOOL EDUCATION: TEACHERS' OPINIONS
}

\author{
Rasa Braslauskienè \\ Klaipèda University, Lithuania \\ Reda Jacynè \\ Klaipèda University, Lithuania \\ Aida Norvilienè \\ Klaipèda University, Lithuania \\ Sada Ramanauskienè \\ Klaipėda University, Lithuania \\ Neringa Strazdienè \\ Klaipèda University, Lithuania
}

\begin{abstract}
The Council of the European Union (2020) points out that the COVID-19 pandemic has had a major impact on education and teaching systems and has fundamentally changed the way we learn, teach, communicate and collaborate within and between our education and teaching communities. The aim of this study is to explore the opinion of pre-school teachers on the opportunities and challenges faced by them in organizing and conducting pre-school education at a distance. The strategy of qualitative research was chosen for the study, Klaipeda city pre-school education teachers were interviewed. The study revealed that teachers did not change the content of education programs, sought to maintain the continuity of education and develop all the competencies of preschool children. Various digital and technical tools for distance education were used. Participants of the educational process experienced a variety of emotions and disturbances. Teachers missed for more decisive action of the institution's administration. The opinion of educators discovered during the research helped to highlight advantages and disadvantages of distance pre-school education.
\end{abstract}

Keywords: COVID-19, distance education, organization of pre-school education.

\section{Introduction}

The global spread of COVID-19 has led to unprecedented disruptions in education around the world that have animated increased interest among policymakers, educators, researchers and the general public in knowing about how education systems have responded to the pandemic and how educational process and teachers' and children's' experiences have changed. There was a need 
to know and to take account of children's developmental levels is necessary, as well as to find online learning tools, which are appropriate and which can promote children's participation and learning (Jinyoung, 2020).

As indicated in the United Nations Publication Policy Brief: Education during COVID-19 and beyond (2020), the COVID-19 pandemic has created the largest disruption of education systems in history, affecting nearly 1.6 billion learners in more than 190 countries and all continents. The crisis is exacerbating pre-existing education disparities by reducing the opportunities for many of the most vulnerable children, youth, and adults. On the other hand, this crisis has stimulated innovation within the education sector. There were innovative approaches in support of education and training continuity: from radio and television to take-home packages. Distance learning solutions were developed thanks to quick responses by governments and partners all over the world supporting education continuity. Despite these actions, the results of a Survey on online and distance learning (2020), which attracted 4,859 respondents from more than 40 countries (of whom $86 \%$ were teachers or school heads), show that, following COVID-19, the majority of teachers (66.9\%) had to teach online for the first time. Additionally, many teachers had problems in accessing technology (computers, software, reliable internet connection, etc.).

On the basis of the conducted studies, J. Bertling, N. Rojas, J. Alegre and K. Faherty (2020) claim that a vast body of research has shown that the use of digital learning technologies is associated with learning gains. However, evidence suggests that learning technologies in pre-school education are most effective as supplements to other modes of teaching, rather than as replacements for more traditional approaches (Donohue, Johnson, Lucas, Lynd, Mukerjee, Thouvenelle, 2020). Distance education became ubiquitous as a result of the COVID-19 pandemic during 2020. Because of these circumstances, online teaching and learning had an indispensable role in early childhood education programs, even though debates continue on whether or not it is beneficial for young children to be exposed extensively to Information and Communication Technology (ICT). Early childhood teachers' efficacy in using technology is another issue in the effectiveness of distance education. The attitudes and skills of early childhood teachers in the use of technology also affect children's motivation and learning. Early childhood teachers often use technologies in their teaching, but usually as teaching tools to show pictures or videos. They need to take on additional roles if they are to teach online (Kalogiannakis, 2010).

The aim of this study is to explore the opinion of pre-school teachers on the opportunities and challenges faced by them in organizing and conducting preschool education at a distance.

Methods: analysis of scientific literature and documents, qualitative research (interview), qualitative content analysis. 


\section{Methodology of Research}

In order to determine the challenges and opportunities faced by pre-school education teachers while organizing distance education during the Covid-19 quarantine, methodology of qualitative research was chosen (Creswell, 2014; Žydžiūnaite, Sabaliauskas, 2017). The interpretative paradigm (Cohen, Manion, Morrison, 2007) and the constructivist approach (Berger, Luckamann, 1999) were used to justify the research. They are adapted in order to provide an interpretive, holistic view of the analysed situation, the "experiences" of persons involved, and an explanation arising from the analysis of the situation. A semi-structured interview method was chosen. In planning research questions, six topics were identified: assessment of the situation (in the context of administration and employees); organization of educational activities while conducting distance learning; assessment of children's achievements and progress in the analysed situation; feelings, experiences of teachers, children and parents; advantages and disadvantages of distance pre-school education and the preparation strategy for future distance education. Research was carried out in October-November 2020. A targeted, criteria selection of research participants was applied. The main criterion was the pre-school education teachers, who worked remotely in spring 2020, during the Covid-19 quarantine. An invitation to participate in the research was sent to all Klaipeda city educational institutions providing pre-school education. Research participants. 15 pre-school education teachers of the Klaipeda city (Lithuania), who have worked remotely in spring 2020, during the Covid-19 quarantine agreed to participate in the research. Demographic characteristics of the research participants: all research participants were female, whose average age was 51 years, average pedagogical experience of teachers was 28 years. Of these, there were four teachers, four senior teachers, and seven teacher-methodologists.

Data collection and analysis. Research participants were sent a consent form, which contained all the information about the organization of the research: aim of the research, process, assurance of confidentiality, duration of the research, etc. After receiving signed consents, research time with each participant was agreed upon. Conversations were conducted remotely using the ZOOM application. Conversations were recorded. The total duration of individual conversations is more than 8 hours and 65 pages of transcribed text. Confidentiality is maintained, personal data of research participants were depersonalized and the research material is available only to the researchers. Research data were processed using qualitative content analysis. Each transcribed text was read by the group of researchers. The text is read in order to form an overall picture, essential sentences or their parts related to the analysed topic were highlighted. The text is divided into key units, which are represented by phrases, 
Braslauskienè et al., 2021. Opportunities and Challenges of Organizing and Implementing Distance Pre-School Education: Teachers' Opinions

sentences, keywords, directly related to the phenomenon under analysis, key units are grouped in order to combine them into an overall structure. In case of further questions, everything was once again clarified with the research participants. After the research report was prepared, informants were offered to get acquainted with it. Informants provided no comments. In presenting research results, statements were presented in coding, e.g. M1, M2, etc. The language of the teachers' speeches was not corrected. The article presents only a part of the research results: the situation of education in the educational institution after the announcement of quarantine: the adaptation of the administration and teachers of the educational institution; peculiarities of the distance education process: content of education, organization of the educational process.

\section{Research Results}

The research sought to find out how pre-school education teachers assessed the situation of education in their educational institutions after the announcement of quarantine in Lithuania due to COVID-19. The research revealed that a distant organization of pre-school education was a challenge for all participants of education: administration of institutions, teachers and parents.

In order to assess circumstances in the educational institution after the announcement of quarantine in more detail, interest was taken in how administration and employees responded to the changed situation. The following actions of the administration and teachers of the educational institution became apparent (Fig. 2).
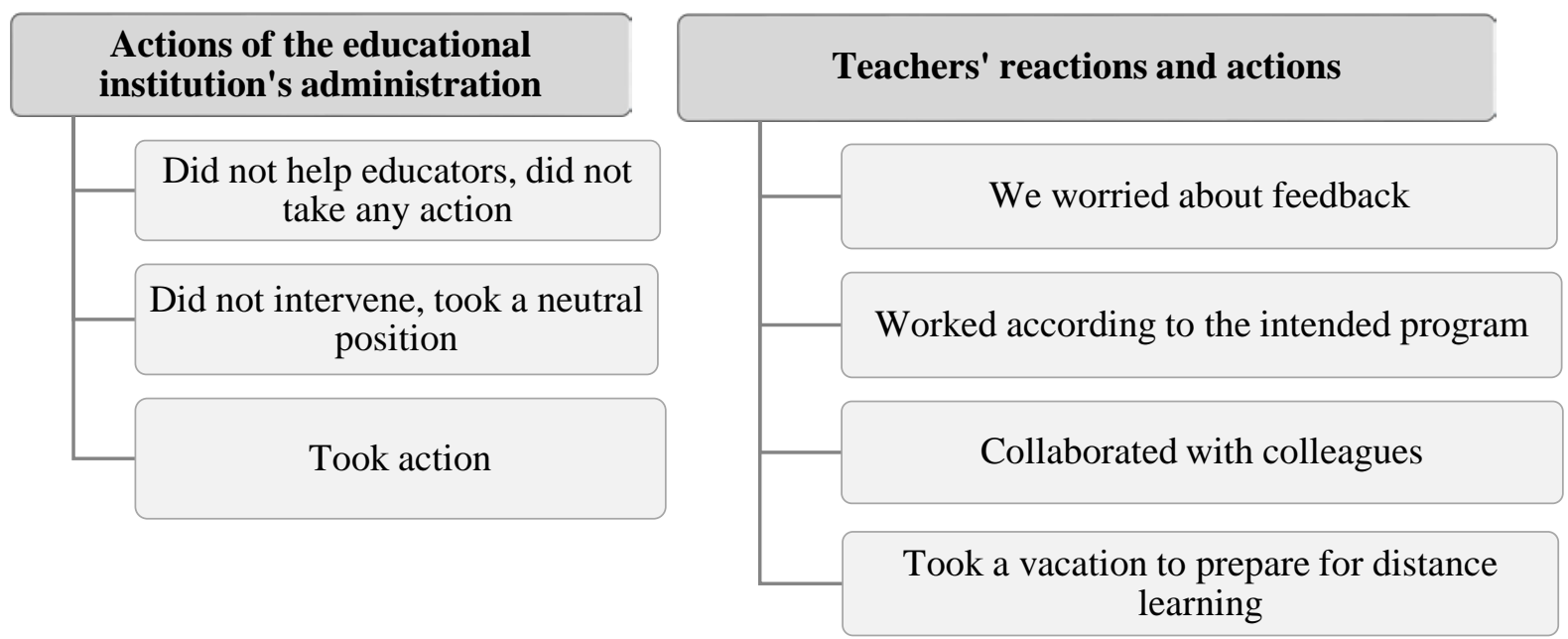

Figure2 Actions of the Administration and Teachers of the Educational Institution after the Announcement of Quarantine 
According to teachers, administrative staff took the following steps: trusted the educators, supported and comforted them (2), e.g.: "administration supported us $\langle\ldots>$ even comforted, that girls be calm, we will manage with everything, we will do it" (M4); reacted quickly, created a joint group, offered to participate in trainings (4); endorsed the teachers' suggestions, discussed, provided recommendations (2), e.g.: "The director of the institution $<\ldots>$ created a "Classroom" group on the Google platform, where we, educators, received all the information about remote activities: getting acquainted with the orders of the Minister of Health, filling in questionnaires, use of information technologies, links, access to seminars - Webinars, conferences for teachers on the "Zoom" platform, and the involvement of educators, and sharing of various activities that took place in Lithuania" (M7).

However, there were teachers, who lacked the initial more decisive actions of the institution's administration. Some educators claimed that the administration of the educational institution did not help and did not take any actions: did not help, did not provide recommendations (3), there was no system created in the institution (2), e.g.: "The administration, to tell you the truth, left the employees behind $<\ldots>$. They didn't help us much, we just expected more of that, advice, how to do, what to do, and we were left to our fate, they advised that maybe do everything remotely and that's all" (M2). One informant stated that the administrative staff of her educational institution did not intervene and left the pre-school education process to chance (1).

The analysis of the initial reaction and actions of educators highlighted the following circumstances (Fig. 1): emotional reaction of educators: worries about pre-school children's achievements and feedback in order to qualitatively prepare for learning at school (1), e.g.: "We were worried a lot $<\ldots>$ that there would be no feedback from parents, but we received, of course, not one hundred percent, but that anxiety gradually subsided" (M3). In their speeches, teachers emphasized that they had collaborated with colleagues, and that was particularly important at the beginning of distance learning (5); worked according to the intended program (1); one educator mentioned that she took a vacation to prepare for distance learning, e.g.: "Somehow, we friendly agreed upon who was on vacation, who was working $<\ldots>$. A colleague took a vacation" (M4).

It was sought to find out how the adaptation of activities to distance education in pre-school educational institutions and groups was carried out. The tools used by teachers for distance learning could be divided into 2 main types: information communication technologies (hereinafter: ICT) and traditional tools. The used ICT tools consist of the following 4 groups: online platforms and social networks; digital programs; applications for creating educational materials, and educational games; smart digital devices (Fig. 3). Traditional tools are tasks in 
Braslauskiene et al., 2021. Opportunities and Challenges of Organizing and Implementing Distance Pre-School Education: Teachers' Opinions

exercise books; various assignments from aids; tasks that develop fine and gross motor skills, etc.

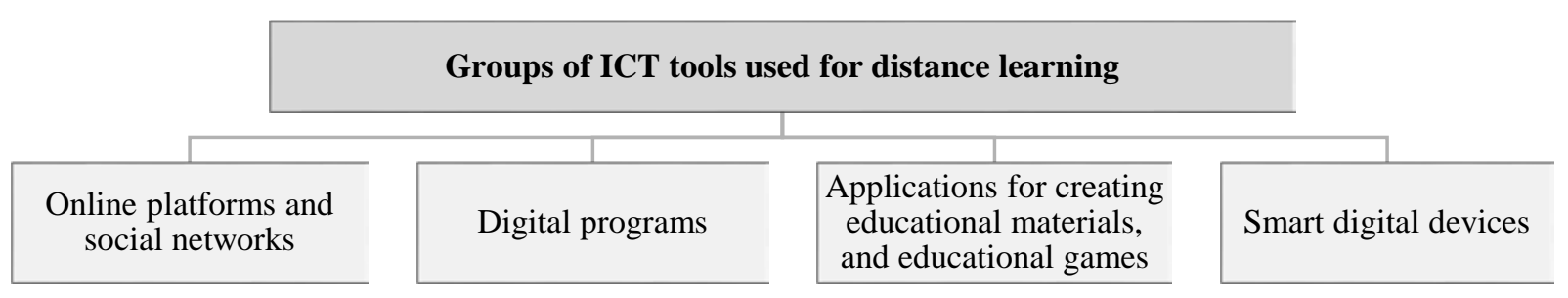

Figure 3 Groups of ICT Tools Used by Educators for Distance Learning

ICT tools were mostly emphasized by the informants. The vast majority of educators used Facebook groups, created them and invited parents to join, or used parent-created ones (14). Some educators (4) used the electronic gradebook Musudarzelis.lt or the electronic learning environments EMA (2) and Eduka.lt (1). All teachers (15) used emails and the Google platform, some (3) used Youtube and Pinterest (1). In order to maintain close contact with parents and ensure the continuity of children's education, educators used various online applications. The most popular and commonly used were Zoom (7) and Messenger (5). Skype (4), Viber (2), WhatsApp (1), Googledrive (2) were used. In developing educational tools, not only did educators use the already mentioned platforms, but also created educational materials and games using various digital programs: Padlet.com (5), PowerPoint (2), Bookcreator.com (2), Worldwall.net (2), LearningApps.org (1), Jigsawplanet.com (1), Mudubudu.lt (1). Educators used various digital programs not only to keep in touch with children and their parents, but also to create educational materials and educational games. When asked about which smart devices were used for distance learning, it was revealed that all educators (15) used personal mobile phones, almost all (14) used computers, and a small part (2) used tablets, e.g.: "A computer, tablet and a smartphone were the main tools" (M15). Some informants (2) mentioned that they had a possibility to take a computer from the educational institution home (but it was not necessary), e.g.: "We used our phones. If a computer was needed, it was possible to take it from the kindergarten" (M5), and one (1) informant mentioned that one had to work using only a personal phone and a tablet, e.g.: "The kindergarten didn't give me a computer. So I had a tablet. That's why the phone, tablet were the main tools. We used our personal means" (M9).

In addition to the ICT tools, the majority (11) of the respondents used traditional ones: "Opa Pa” workbooks (11), e.g.: "We worked in accordance with the "Opa Pa" methodology" (M6), exercise books (7), other teaching aids (11) for drawing, writing, development of fine and gross motor skills, music and non- 
formal education, e.g.: "I've pointed out which pages should be done from the notebook that children had at home. I've shared morning exercises, audio tales and poems that were necessary according to the educational materials in a closed FB group..." (M10).

It was sought to determine whether educational goals have changed, what were the main tasks set during the period. Changes in educational goals and tasks are shown in Figure 4.
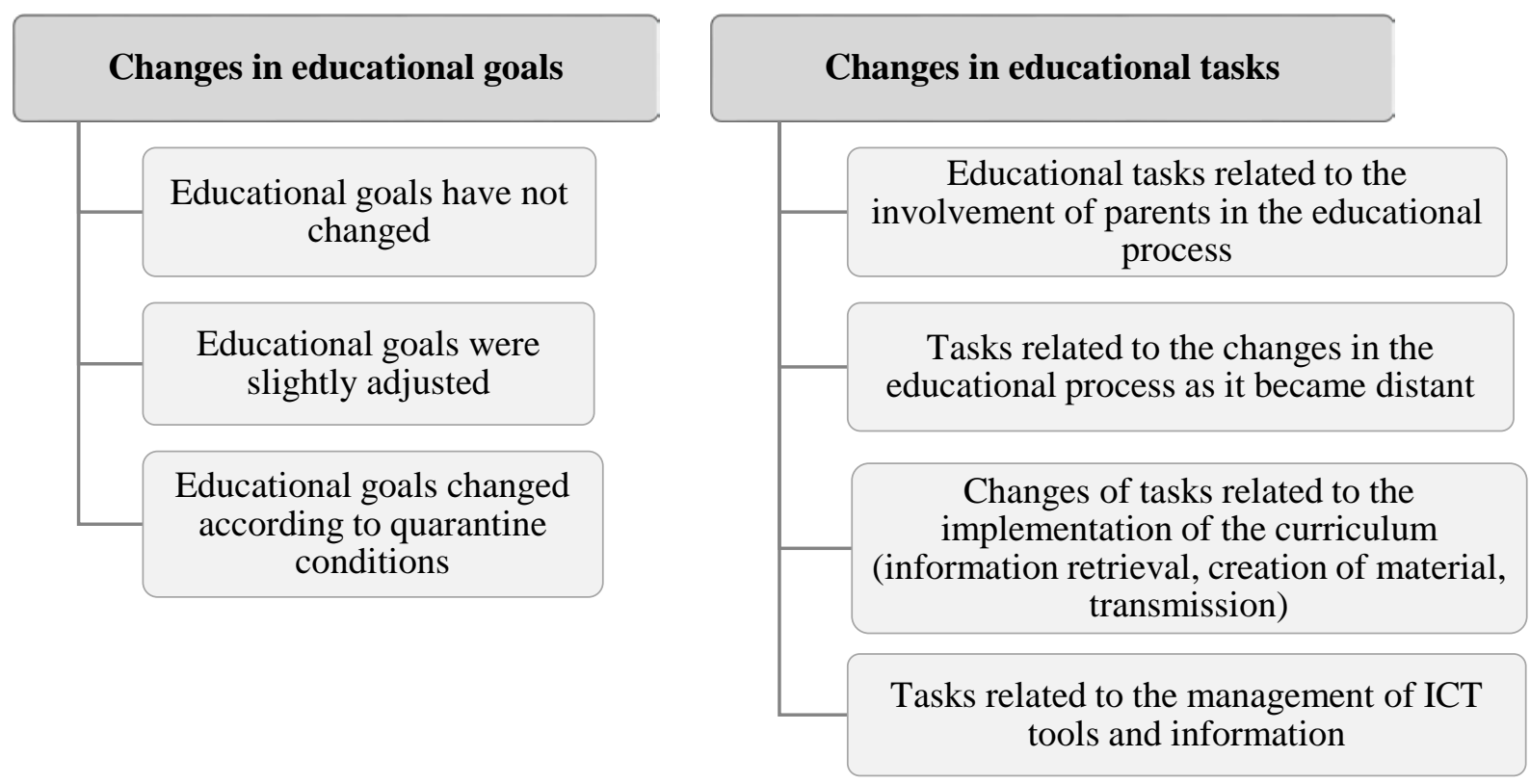

Figure 4 Changes in Educational Goals and Tasks after the Transition to Distance Learning

Informants stated (4) that educational goals did not change significantly, e.g.: "No, educational goals did not change" (M4). However, they were adjusted by taking into account the existing situation (9), e.g.: "We adjusted the goals by taking into account that we could not implement all the activities..." (M3). A small number of educators (2) indicated that the goal did change, e.g.: "The educational goal had changed, as parents had to get actively involved, participate in performing various tasks. There was no longer direct communication with children" (M7).

The main tasks indicated by the majority of informants (8) were the involvement of parents in the educational activities and the interest of children and parents in the educational process and tasks provided (6), to adapt to the needs of parents, to establish a sincere connection with them (11), e.g.: "One of the tasks: to convey most comprehensive learning materials to parents, to assign enough tasks so that everyone can select them according to their individual needs and develop properly" (M10). Some informants (5) pointed out that, first of all, it was 
Braslauskiene et al., 2021. Opportunities and Challenges of Organizing and Implementing Distance Pre-School Education: Teachers' Opinions

necessary to find the most appropriate ways to contact and maintain constant connection with parents, provide them with information about the continuity of the educational process, consult on issues related to education, in individual cases provide pedagogical psychological assistance, as well as help manage stress (3), e.g.: "The most important thing was to be able to organize everything, be able to communicate and cooperate with parents, pupils of the group [...] to ensure the continuity of pre-school education at a distance, so that there is mutual sincere feedback from parents and children" (M11).

Educators adjusted the content primarily with regard to the fact that parents would be able to transmit educational tasks to their children, and that the process of children's education would be continuous and purposeful in order to achieve outcomes provided in the General Curriculum Framework for Pre-school Education (2014).

The majority of educators used the pre-school education toolkit "Opa Pa" (11), e.g.: "...we used the "Opa Pa" toolkit, [...] we were guided exactly by the "Opa Pa" program" (M3). Some educators used this tool, but adjusted the order of topics (5), duration of education (3), e.g.: “...we have expanded some topics up to two weeks. It turned out that it was necessary to work longer" (M9), adapted tasks to home conditions (9). Teachers consulted with parents on how to work remotely (5), searched for examples of tasks (2), selected tasks so that children could perform them independently (2), e.g.: “...since it was already the beginning of spring [...] we simply selected [...] tasks that children could perform independently" (M4), prepared integrated tasks (4), e.g.: "According to the topic chosen for the week, we offered to perform simple exercises, tasks for developing fine motor skills, as well as to perform mathematical tasks in developing children's logical thinking" (M11).

Informants state that they prepared tasks by collecting and systemizing information from various sources, searched for technical solutions (14), used video materials, made video clips, created short films and educational games (10), e.g.: "We adjusted the content to make it interesting for children. We searched for short films on the topic, systematized information" (M5). Teachers sent parents information on how tasks should be completed (5), e.g.: "We searched for different ways of contacting parents so that they would understood how to perform activities, would complete them" (M5), suggested parents to make use of the available home spaces (1), tried for the tasks to be interesting for both children and parents (14), e.g.: "When choosing the content of education (topics, activities), I sought to make them clear, fun, interesting for everyone - not only for educators, but also for the family, and especially for children" (M15). Educators sought to develop all children's competencies, thus got together and worked as a team: educator, speech therapist, teacher of arts and non-formal education (5), e.g.: "Speech therapist sent the exercises" (M11). "The non-formal 
education teacher joined in: PE teacher showed exercises to be performed outdoors. We collaborated with other teachers and music teacher and others, we worked as a team" (M9).

High workload and working time related to the necessity to prepare and provide teaching materials in a distant way, were distributed by educators in a variety of ways. Some educators joined together in groups, distributed topics, prepared teaching materials and tasks, and shared them with each other (7), e.g.: "We've divided among 3 groups who would prepare what material: nature, mathematics, hand training, reading, etc. We shared accumulated and prepared materials. Jointly to make it easier" (M8). Other educators worked individually and prepared all the educational material on their own (3).

Some educators (7) did not perform activities directly with children, e.g.: "There was no direct contact with children. We communicated with parents. We carried out distance education through them" (M5). Educators prepared teaching materials, tasks, and sent them to parents daily (4) or once a week at a specified time (6), others connected directly once a week (6), e.g.: "Our distance lessons were held at 4 p.m. By that time, parents had already finished their work. We agreed upon that, we sought that, we wanted them to help their children. Because parents were really benevolent" (M6). Some educators connected several times during the whole period of quarantine (2). The nature of communication with parents and pupils is illustrated in Figure 5.

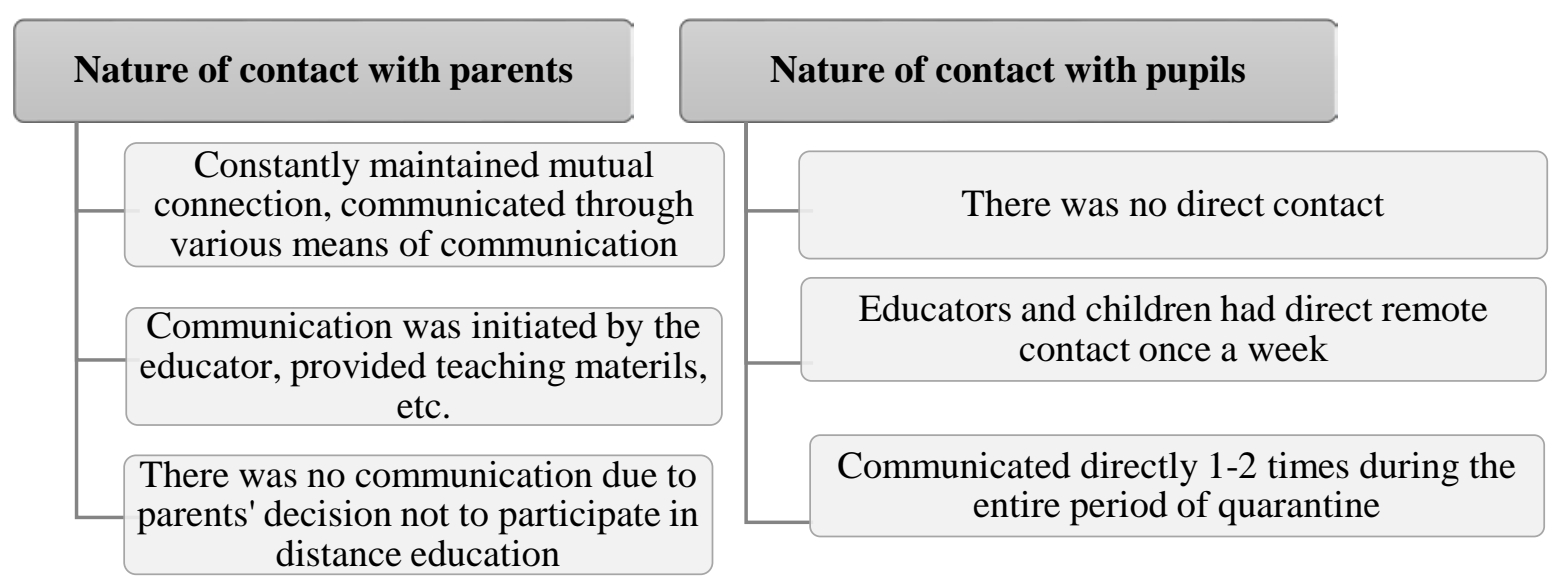

Figure 5 Nature of contact between the educators and Pupils and Their Parents during Distance Learning in the Period of Quarantine

Educators claimed that they were accessible to parents by various means, remotely provided individual consultations: by phone, email, Skype, Messenger, Viber, and other means (7), e.g.: "We chose easier-to-manage conference calls by Messenger, Skype programs. With their help we shared insights, observations, explained what is good, what was successful, and what still needs to be improved" 
Braslauskiene et al., 2021. Opportunities and Challenges of Organizing and Implementing Distance Pre-School Education: Teachers' Opinions

(M12), "Individual conversations were held using Viber, Messenger, Zoom platforms” (M11).

Some educators (3) mentioned that they conducted parents' surveys, during which they found out that parents would like to receive a curriculum, teaching materials and assignment for a week, e.g.: "A parent survey was conducted on what is better for them..." (M5).

Educators received feedback from children's parents on the outcomes of education, completed tasks, children's works, in various ways. Some educators indicated that they had a hard time doing that (4), e.g.: "But somehow the number of participating parents and children started to decrease..." (M1). However, a larger part of respondents were happy with the parents' activity and encouraged them to provide feedback by posting their children's works and completed tasks on the Padlet board (2), parents themselves shared their children's works in a closed Facebook group (3). During quarantine, there were individual cases (2) when the educational process was interrupted by the parents' decision while they were in quarantine, e.g.: "Only one family was not connected. They said they had no means, were self-isolating and would not participate" (M6).

Several educators mentioned that during this difficult period, they participated in republican projects (2) and carried out an international project (1), e.g.: "Parents together with children participated in project activities. There were republican projects, children with parents participated in projects: "Mommy is a part of my heart", "My mommy is the most beautiful". International project "Where the Easter egg will roll", in which children of my group participated. Participants were from England, America" (M13).

\section{Conclusions and Discussion}

\section{findings: \\ The analysis of the qualitative research results highlighted the following}

The organization of distance education, after the announcement of quarantine in Lithuania, posed new challenges for all participants of pre-school education: administration of educational institutions, teachers, parents. Some teachers lacked leadership of the heads of the educational institution in making responsible decisions about the organization of distance education. Other teachers claimed that the administration of the educational institution had taken actions: supported, calmed down, quickly reacted, discussed, offered to participate in trainings, provided recommendations.

- $\quad$ Educators tried not to change the goals set in the General Curriculum Framework for Pre-school Education (2014) and to achieve them, but adjusted educational tasks by taking into account the changed situation 
in terms of quarantine. Educators were able to quickly master digital programs, manage information flows, cooperate with colleagues and parents, maintain the continuity of pre-school education, individually respond to the situation of each child. Teachers used ICT and traditional tools for distance learning. Educators adjusted the content, first of all, with regard to the fact that parents would be able to transmit educational tasks to their children, and the process of education for children would be continuous and purposeful. In order to provide feedback to parents, teachers used various ways that were most easily managed and accessible to parents. Teachers constantly provided individual consultations for parents on all issues related to their children's education.

Research limitations and possibilities for research continuity. The limitation of the qualitative research is related to the inevitable subjectivity in the qualitative research. Even though when planning and conducting the following research requirements for this type of research were met, the generalization of results and possibilities of their application are limited in part by the small number of research participants. It would be incorrect to apply the findings of the research to all pre-school education institutions, but it is likely that the opinion expressed by the participants of research allow to predict continuity of the further research on the following phenomenon in order to find out the opinion of parents and single out the most important steps in organizing distance education.

\section{References}

Berger, L. P., Luckmann, T. (1999). Socialinis tikrovès konstravimas: žinojimo sociologijos traktatas. Vilnius: Pradai.

Bertling, J., Rojas, N., Alegre, J., Faherty, K. (2020). A Tool to Capture Learning Experiences During COVID-19: The Pisa Global Crises Questionnaire Module OECD. Education Working Paper No. 232.

Cohen, L., Manion, L. Morrison, K. (2007). Research methods in education. (6th ed.). New York: Routledge.

Creswell, J. W. (2014). Research Design: Qualitative, Quantitative and Mixed Methods Approaches (4th ed.). Thousand Oaks, CA: Sage.

Donohue, Ch., Johnson, A., Lucas, P., Lynd, Ch., Mukerjee, J., Thouvenelle, S. (2020). Distance Learning and Early Childhood Education. Retrieved from: https://eclkc.ohs.acf.hhs.gov/professional-development/article/distance-learning-earlychildhood-education

Jinyoung, K. (2020). Learning and Teaching Online During Covid-19: Experiences of Student Teachers in an Early Childhood Education Practicum. International Journal of Early Childhood, Vol. 52, p. 145-158. Retrieved from: https://link.springer.com/article/ 10.1007/s13158-020-00272-6 
Braslauskiene et al., 2021. Opportunities and Challenges of Organizing and Implementing Distance Pre-School Education: Teachers' Opinions

Kalogiannakis, M. (2010). Training with ICT for ICT from the trainer's perspective. A local ICT teacher training experience. Education and Information Technologies, 15(1), 3-17. Retrieved from: https://link.springer.com/article/10.1007\%2Fs10639-008-9079-3

Policy Brief UN. (2020). Policy Brief: Education during COVID-19 and beyond. Retrieved from: https://www.un.org/development/desa/dspd/wpcontent/uploads/sites/22/2020/08/ sg_policy_brief_covid-19_and_education_august_2020.pdf

Priešmokyklinio ugdymo bendroji programa. (2014). Retrieved from: https://www.smm.lt/ uploads/documents/Prie\%C5\%A1mokyklinio\%20ugdymo\%20bendroji\%20programa(3) .pdf

School Education Gateway. (2020). Survey on online and distance learning. Retrieved from: https://www.schooleducationgateway.eu/en/pub/viewpoints/surveys/survey-on-onlineteaching.htm

Tarybos išvados dèl kovos su COVID-19 krize švietimo ir mokymo srityje. (2020). Europos Sajungos oficialusis leidinys, C 212 I/9. Retrieved from: https://eur-lex.europa.eu/legalcontent/LT/TXT/PDF/?uri=CELEX:52020XG0626(01)\&from=EN

Žydžiūnaitė, V., Sabaliauskas, S. (2017). Kokybiniai tyrimai: principai ir metodai. Vilnius: Vaga. 